\title{
The damaging effects of romantic mythopoeia on Khoesan Linguistics.
}

\author{
Menán du Plessis, \\ Research Associate in Linguistics, \\ Stellenbosch University
}

Abstract: The paper outlines some basic guidelines that should inform studies in Comparative Linguistics, and notes a tendency in contemporary Khoesan Linguistics for these to be neglected, while pre-theoretical assumptions of 'ancientness' and 'otherness' take their place. The paper demonstrates the damaging effects of this romanticism through two brief case-studies - one concerning the supposedly primordial stratum made up of the JU and !UI-TAA languages, and the other concerning a conjectured intermediate stratum made up of the KHOE (or 'Khoe-Kwadi') languages. It is concluded that the construction of these linguistic layers, so neatly in agreement with the layers proposed in certain models of southern African population history, has been enabled by a willingness to believe that perceptions of otherness have some absolute and meaningful value, and that they take precedence over fundamental principles.

Keywords: Khoesan, Bantu, linguistics, metatheory

\section{Introduction: On guiding principles in Linguistics.}

In its primary task of theoretical analysis and description, Linguistics aspires to be a science. Yet, somewhat reluctantly, we have to acknowledge that there are many respects in which it cannot truly claim to be one. Linguists cannot speak with any great confidence about experiments and replicable results, just as they cannot write formulae that will invariably hold true, or invoke some constant value for a rate of change. Nevertheless, as the discipline has grown and developed over the past two centuries or so, our basic knowledge has expanded considerably, so that we now have a better understanding, for example, of the great range of linguistic typologies that exist around the world, and the ways in which languages tend to change. The discipline has also had its share, like any other, of wrong turnings. Out of all these slow processes, including lessons learned from the history of the discipline itself, as well as reference to the general philosophy of science, certain fundamental principles have come to form the basis of sound reasoning in Linguistics.

These guidelines include:

1. The principle that differences of a physiological or cultural nature do not preclude the possibility that the languages of the communities concerned might be related.

Neglect of this principle in the context of southern Africa accounts for the long time it took for linguists to recognise that the languages spoken by the Khoi-Khoi of the countries today known as South Africa and Namibia were in fact related to languages spoken by some of the 'Bushmen' or 'Masarwa' of modern Botswana. Although some of the typological and morphosyntactic affinities of the Khoe languages were already apparent by the early part of the $20^{\text {th }}$ century, ${ }^{1}$ it seems that arrival at

\footnotetext{
${ }^{1}$ Dorothea Bleek (1927) invoked a category of 'Central Bushman' for Kalahari varieties such as Naro and an eastern Kalahari variety described by Dornan (1917), which she perceived as being 'a link between the Northern Group and Hottentot' (p.58). Beach (1938:4) observed that Dorothea Bleek's Comparative Vocabularies of Bushman Languages (1929) made it seem 'certain that there is a fairly close connection between Hottentot and Miss Bleek's “Central Bushman languages, particularly Naron', but added, almost as an afterthought, that it might be said 'that the language of the Naron [...] is really not Bushman at all, but simply a dialect of Hottentot'. While this last point seems obvious today, it was some while before scholars like Maingard (1963) and Köhler (1971) began to point out the systematic correspondences that clearly indicated the reality of this
} 
the obvious conclusion was inhibited by an unshakeable belief that differences in physical appearance and economic culture were markers of some actually significant divide.

2. The converse principle that resemblances of a physiological or cultural nature do not constitute evidence that the languages of the communities concerned are related.

This principle was given formal expression by Joseph Greenberg, following his (1963) dismantling of the 'Hamitic' hypothesis as developed by Meinhof (1912) amongst others. The Hamitic hypothesis proposed a set of far-flung connections between various languages from groupings that we would today identify as Niger-Congo, Nilo-Saharan, Afroasiatic, and Khoesan (or Khoisan) - and where the Khoesan candidate for membership was Nama. ${ }^{2}$ The affiliations were suggested on the basis of a few elements of similar morphology, and various lexical items that bore a faint resemblance to one another. What made the 1912 version of the hypothesis particularly reprehensible (or ridiculous) was the appeal to biology for corroboration: Die Sprachen der Hamiten included a chapter by Felix von Luschan, in which he attempted to prove parallel affinities of the relevant speaker populations on the basis of measurements he had taken of people's noses.

3. The principle that it is advisable to have a reasonable comparative knowledge of other languages occurring in the neighbourhood of a language under study.

The dangers of a narrow focus were pointed out by Samarin, in the context of comments by him (1971:230) on Tessmann's early study of the special languages used by young Gbaya-speaking men during their initiation into the West African secret societies of the Labi and To. Tessmann, who was primarily an anthropologist, speculated (1931) that these languages might have preserved certain ancient or 'original' features. As Samarin noted, Tessmann was perhaps predisposed to imagine he was seeing evidence of ancientness because of his prior belief in the primitiveness of the society he was studying. In addition, Tessmann's ignorance of neighbouring languages meant that he failed to detect various borrowings: Samarin, for example, identified a Central Saharan base for Labi, and an Adamawa (Niger-Congo) base for To.

4. The general and overarching principle of parsimony, that the simpler explanatory hypothesis is to be preferred - at least in the first place - over one of greater complexity.

The good sense of applying Occam's razor in the context of Linguistics has been pointed out on a number of occasions by the historical linguist and metatheoretician Roger Lass in his discussion, for example, of situations where borrowing might be invoked as one of several explanatory scenarios (1997); and also with regard to choosing between alternative candidates that might be projected as proto-segments in the context of linguistic reconstruction (1993). ${ }^{3}$

These four rationalist principles are among the fixed stars that should guide us in our modern practice of Linguistics. As long as we keep them in sight, we have a fair chance of not losing our way, even when we enter a little-known linguistic territory, such as the field of Khoesan languages. As already noted, some of these guidelines were arrived at as a consequence of lessons learned from past errors. Since some of these historical false turnings were made in the context of studies in African languages, it is dismaying that we occasionally find these hard-won principles flouted or ignored in current

familial unity. An early set of reconstructions for the family was postulated by Baucom (1974), to be superseded by those offered by Vossen (1997).

\footnotetext{
${ }^{2}$ Nama is a southern dialect of Namibian Khoekhoe, and is also spoken in South Africa. Northern varieties include Dama and HaillOm.

${ }^{3}$ Linguistic 'reconstruction' involves the extrapolation of a hypothetical ancestral language that could plausibly have given rise to a range of actually observed offspring languages. The process begins with the assembly of arrays of comparative series consisting of cross-varietally distributed words that have similar meanings and display repeated phonetic correspondences (but not necessarily identities). On the basis of known or universally likely sound shifts (such as *ki > /si/), a set of sounds is then postulated for the 'proto-language'. Known 'weak spots' in the process concern the quality and quantity of data used for the initial arrays, assumptions about the nature of phonetic correspondences, and assumptions about the directionality and naturalness of sound shifts.
} 
Khoesan linguistic studies - and in their place an all too frequent reliance on beliefs concerning the 'ancientness' or 'otherness' of the Khoesan languages.

\section{Romances concerning the 'ancientness' and 'otherness' of Khoesan (or Khoisan) languages.}

Belief in the 'ancientness' of the Khoesan languages, sometimes allied to a notion of their primacy, as well as conjectures about a former carpeting of Africa in a now almost entirely lost Khoesan linguistic substrate, are sometimes expressed even by the current generation of linguists. Only twelve years ago, for example, Sands (2001:204), wrote as follows:

It is widely assumed that Khoesan languages were once spoken from southern Africa continuously to eastern Africa. Oral tradition speaks of "Bushmen"or Twa in Zimbabwe and elsewhere, and the Twa (Kwadi) of southwestern Angola became extinct only recently. The presence of Sandawe-type words in the Cushitic language Dahalo of coastal Kenya is clear evidence Khoesan languages once had a greater distribution. But even within the "Khoesan" area of southern Africa, we must not assume that the Khoesan groups were limited to their historically-attested distribution.

It is mistaken, of course, to think that use of the name 'Twa' implies some kind of specific 'Khoesan' identity or that communities referred to in this way necessarily spoke a Khoesan language: the name is widely applied, and is typically a pejorative exonym. (The reconstructed Proto-Bantu, root *-tóà 'pygmy, bushman, servant' includes the variant *-tóá, with the broad meaning 'member of neighbouring despised tribe' or 'bush dweller'.)

Beliefs of this kind on the part of linguists appear to arise in part from uncritical acceptance of the 'layer cake' model of southern African population history, where the first layer consists of an original population of hunter-gatherers. Since most speakers of the modern Ju and !Ui-Taa languages still preserved until very recently a hunter-gatherer mode of existence, it seems that we have thought it fair to conclude that they must be the direct and unique descendants of this earliest (or 'Stone Age') layer - and hence that their languages too must be ancient. In some cases there even appears to be an extreme version of this belief in play, namely that the Khoesan languages are not only ancient, but have failed to undergo any normal processes of change, so that they are imagined to be 'fossil languages' - or languages caught in amber - supposedly with the potential to provide insights into aspects of early human language as it was still evolving. ${ }^{4}$

Conversely, since the archaelogical record for southern Africa shows that domesticated animals and iron tools start appearing only in relatively recent strata, it has seemed reasonable to draw the neat conclusion that this layer must have been contributed by a much later group of 'Iron Age' immigrants, who - it is assumed - would have been speakers of various early Bantu $u^{5}$ languages. While it may have been a popular argument at one time that various words associated with a distinctive 'Iron Age' culture could be reconstructed for Proto-Bantu, it has long since been demonstrated that almost all of these words are adaptations of older words with more basic meanings (De Maret and Nsuka 1977).

\footnotetext{
${ }^{4}$ A similar primitivist essentialism even finds expression in some of the iconography associated with one of South Africa's leading universities, which as recently as 2012 launched a unit intended to focus on African linguistic diversity, with particular emphasis on Khoesan languages, where the unit's logo features a child's drawing of a crude stick figure, with lines of 'speech' issuing from an overly large, seemingly infantile head.

${ }^{5}$ As noted in the footnote to a previous work (Du Plessis, Forthcoming), the term 'Bantu' was invented by Wilhelm Bleek (1862:3) as a label for a very large grouping of related languages within Benue-Congo, itself a subset of the Niger-Congo super-grouping of related language families. This abstract linguistic term was later misappropriated and abused by the apartheid regime in South Africa, being used in a generally contemptuous manner as a way of referring to black African people. As a consequence, South African linguists find it difficult even today to use this term in its original, neutral sense, and some have suggested alternative names for the family, such as Kintu or Sintu (see footnote 3 to Herbert and Bailey 2002). These have not taken hold, though, perhaps partly because the negative connotations are specific to the unique historical experience of people in South Africa, and partly because that country is home to only a few languages of this vast family, which has been variously estimated to consist of anything from 300 to 680 languages (Nurse and Philippson 2003:2-3).
} 
For example, one of the words commonly used for 'iron' or 'metal' (such as Zulu insimbi) arises from a word meaning 'cowrie'. Words used for 'ore' are either older words for 'stone' or 'rock', or may be nominalisations (such as Nyanja ntapo) from a verb meaning 'take out honey or clay'. Likewise, words for 'smithing' seem to develop from words meaning 'beat, pound' or alternatively, 'blow'; while further words for 'iron' are nominalisations from such verbs.

While some linguists (Schadeberg 2003) still allow that the earliest speakers of Bantu languages might have been making pottery and herding goats, we should note that the reconstructed word meaning 'heap up, mould' (*- búmb-) does not necessarily imply the making of pots, but may originally have had a general meaning more simply associated with the shaping of clay walls or fishing weirs. Lastly, we might note that words used in some southern Bantu languages for 'goat' were originally terms for species of antelope (such as *-bùdì 'kudu', or *-bàdì 'reedbuck'). Indeed, the Khoekhoe word for 'cow' (found in Nama as goma) appears to be another Bantu word for 'kudu' (found, for example, in Nyanja as mngoma).

On the other hand, the reconstructed vocabulary of Proto-Bantu contains hundreds of words that are plainly associated with a primary culture of hunting, trapping, fishing and gathering, while individual Bantu languages typically have even richer repertoires of such terms, which may include, for example, special names for the various methods of gathering winged ants (Van Warmelo 1989:278), as well as terms for different types of arrows, including 'toy' arrows (or bird arrows), bird snares, small-game traps, pitfall traps and game-guiding fences (Scott and Hetherwick 1957: throughout). The very lore of hunting is embedded in the vocabularies of Bantu languages, as, for example, in Venda, where tshitula-nama was a traditional name for either a moth or a "species of small bird that used to come in swarms, believed to augur meat' (Van Warmelo 1989:426).

With all this in mind, it seems doubtful that early speakers of Bantu languages would have left any visibly distinct cultural signature in the material record, while the archaeological evidence for the first presence of domesticated animals and ironware in the southern region cannot be extrapolated to mean anything more than that these things (and perhaps the associated 'know-how') found their way by slow processes of diffusion (which might indeed have included some migration) to populations that were already here, and who may well have been speakers of early Bantu varieties.

Sandwiched in between these two layers, some have proposed that there might be a filling of somewhat earlier herders, speaking languages belonging to the Khoe family. This idea, which has a long history, has been given a contemporary reformulation by Güldemann (2008), who develops a theory of staggered arrivals of different linguistic communities into southern Africa, in a neat matching of the population model. The arguments will be discussed in more detail below.

In reality, none of the Khoesan language groupings shows the kind of extensive proliferation that would be commensurate with a great antiquity. Some contemporary linguists (Heine and König 2008) have lately conceded that the Khoekhoe languages in particular must be 'a fairly young genetic grouping', while it now seems, realistically, that the Khoe family as a whole cannot be older than perhaps 2000 years, considering the relatively limited extent of its branching and dialectal divergence. As for the Ju and !Ui-Taa groups, ${ }^{6}$ these reflect no great diversity at all, and each on its own appears to be far younger than the Khoe family. ${ }^{7}$ Of course the term 'old' is relative; and when it comes to the speed of language change, there are simply too many potential variables and intangible factors for us

\footnotetext{
${ }^{6}$ These language groups were named by Westphal (1971) after the basic word for 'person' in each. The revised spelling !Ui seems to date from Güldemann and Vossen (2000).

${ }^{7}$ It is feasible that the Ju and !Ui-Taa groups might be related to each other, and hence could share a common ancestor that would be much older. However, evidence from Historical Linguistics (Du Plessis, 2013; In Preparation) suggests that these two groupings are more likely to be cousins than sisters. The question of what the ancestral language, or related ancestral dialects, might have been is somewhat controversial, and really needs space of its own for presentation of the detailed data and lengthy discussion required. Some of the evidence provided in the present paper nevertheless points, on a preliminary basis, to the possibility of associations of some kind (yet to be determined) involving regional varieties of Bantu languages.
} 
to propose a hard and fast rate. But it seems at least unlikely that either Ju or !Ui-Taa could be very much more than a thousand years old, or perhaps two thousand years at the utmost.

Certainly we do not have a complete record for all of these groups, particularly for the !Ui languages. It is true that speakers of these varieties were among the victims of horrible 'extermination' campaigns carried out by Cape farmers called up on 'Commando' at various times during the $18^{\text {th }}$ century, and the official reports of that period as later published, for example, by Moodie (1838:Part III), record with dreadful matter-of-factness exactly how many hundreds of people were killed. At the same time, the women and children were usually spared and taken to work on farms - which means that their languages at least were not simultaneously wiped out. In some cases the women may have married Khoikhoi men working on these farms, and it is probably on account of an ensuing bilingualism that, by the time IXam was recorded in the late $19^{\text {th }}$ century, the speakers of this !Ui variety had numerous loanwords from Kora in their language. It is possible also that some of these small communities simply moved further away from the Cape, while others entered into new social formations. The Korana people indeed had an orally handed down historical tradition (Engelbrecht 1936:67) that some of their clans had incorporated 'Bushmen' groups.

There are one or two fragmentary records of !Ui varieties that were made before Bleek and Lloyd started their major work on IXam in the last part of the $19^{\text {th }}$ century, including a brief wordlist written down by Lichtenstein (1815, Appendix 1), and another by Wuras (c.1850). During the early and later parts of the $20^{\text {th }}$ century, scholars like Dorothea Bleek (2001), Meinhof (1928/29), Doke (1937) and Maingard (1937) collected more data from small communities of surviving speakers, while further material was later collected by others, such as Ziervogel (1955) and Lanham and Hallowes (1956). Although these documentations are often sketchy, it is still reasonably clear, since lexical items shared across the dialects bear such a very close resemblance to one another, that the varieties of !Ui could not have been vastly divergent. (It is true that $\|$ Xegwi seems to have been more of an 'outlier', but much of the data for this variety was obtained from just a single speaker, while at least some of the words appear to be either loans or innovations.)

Concerning the idea of Khoesan 'otherness', its sources are harder to pinpoint, because there is a sense in which the impression of difference is partly created by unusual linguistic analyses, while at the same time the very licence to engage in an exoticising type of linguistics seems to be granted by an assumption that the discovery of 'otherness' is a desirable possibility. In effect, the myth is selfconfirming, while it undoubtedly derives further power from the adjunct belief in the 'ancientness' of Khoesan languages. Yet, as will be suggested below, supposedly rare or strange features in Khoesan often have a common occurrence in other languages, or else are amenable to simpler explanation.

The remainder of this paper will focus on two of these proposed linguistic strata, and will attempt to show how their theoretical construction has been enabled at least partly by failure to adhere to the basic principles outlined above.

Construction of a 'first layer' supposedly contributed by speakers of the 'primordial' Ju and!Ui-Taa languages.

The Ju and Taa groups both have a system of noun-classification based on a set of multiple genders very similar to those of the Bantu languages. ${ }^{8}$ While these genders are now largely covert, being expressed mainly through pronominal cross-reference, languages of the !Ui and Taa groups make some use of gender-indexical noun suffixes, while both Ju and !Ui-Taa groups have dialects where the nouns still carry prefixes. The existence of only a two-gender system in the !Ui language, IXam, was recognised by Wilhelm Bleek, who nevertheless noted (1911:147) that this was 'probably the scanty remains of a former more extensive classification of nouns'. The !Ui languages are considered

\footnotetext{
${ }^{8}$ A recent study by Heine and Honken (2010) proposes a link between the Ju dialects and Eastern $\neq$ Hoan, and even suggests the name Kx'a for the unified grouping. However, the 'Ju-like' component of the E. \#Hoan lexicon reflects such a close affinity with the lexis of various Ju dialects that it is open to alternative interpretation as borrowed material. This seems all the more likely given that the (greatly reduced) gender system and other structures of E. łHoan bear little resemblance to characteristic features of the Ju varieties.
} 
(Güldemann 2004b) to form a unit with Taa, as implied by Dorothea Bleek's original (1927) classificatory entity, 'Southern Bushman'.

The best known, and most extensively documented member of the !Ui family is IXam. A preliminary contemporary analysis of the language is included in the recently published Routledge handbook, The Khoesan Languages, (Vossen 2013). In this account by Güldemann (2013a) we read (p.242) that:

IXam grams are to a considerable extent similar or identical between nominal and verbal expressions, in spite of the fact that there seems to exist a noun-verb distinction.

Secondly, concerning adnominal modifiers in particular, we read (p.245) that:

Some lexical stems are used predominantly as modifying attributes of nouns; these all occur post-nominally. This functional and structural commonality aside, they reveal hardly any other characteristic in morphological design or grammatical behaviour which would justify subsuming them under the unitary lexical category "adjective". . [...] In general, the data on lexical stems used for the semantic modification of nouns indicate that an incipient closed class of adjectives could exist; at the same time, almost all items concerned still betray the historical fact that they have been recruited from the two major lexical categories, viz. nouns and verbs.

With due respect, it seems fair to say that this characterisation invites us to regard the !Ui languages as not only still nascent, but also 'strange'. We could be forgiven for thinking, on reading them, that we are back in the 1930s, at the time of the great 'Empire Exhibition', when a linguist of that period (Maingard 1937) wrote as follows, concerning another member of the !Ui group:

It will be observed that the traditional nomenclature is not altogether discarded in these studies. It must, however, be pointed out that some of these terms are of doubtful application to ¥Khomani, where, for instance, "verbs" (i.e. words expressing "actions") have all sorts of functions which are represented in our European languages by other "parts of speech". Indeed the European conception of "parts of speech" cannot strictly be said to be true of Bushmen.

In reality, the properties held out to us as so decidedly 'other' are perfectly familiar and normal in the context of other African languages, such as the Bantu languages in particular. Since the Bantu languages typically each have only a few true adjectives (as reflected in descriptions, for example, of Swahili (Ashton 1947:46), Mwera (Harries 1950:52), Mbukushu (Fisch 1998:87), Venda (Poulos 1990:126), Sotho (Doke and Mofokeng 1985:118) or Zulu (Doke 1950:99), ${ }^{9}$ we find extensive use of 'relative stems', plus denominatively derived descriptive stems. Just as in Taa and !Ui, stems used in relative constructions of this kind may include interrogative stems and others with a deictic (or demonstrative) component. Illustration 1 (overleaf) provides examples from two Bantu languages.

As it happens, the !Ui languages have numerous other affinities with southern Bantu languages. These include:

- Use of an 'emphatic' (possibly Topic-marking) particle ke(n), which is used also in Venda and other Bantu languages, where it appears to be a construction incorporating the 'owner' root $(<\mathrm{PB} *(\mathrm{j})$ éné or possibly *(j)éní).

- Use of semi-homophonous yet semantically distinct morphemes (of the type ha) used for a Past and a Negative.

- Use of a Venitive such as saa with Future implication.

- Use of a Possessive morpheme ka.

- Use of a morpheme ka in association with the Adverbial Phrase, much as in Tswana.

- Extensive use of multi-verb constructions comparable to (and sometimes even formally similar to) those of the Sotho-Tswana and Nguni languages. These constructions are used, just as they are in the case of the Bantu languages, to convey various micro-implications of Tense, Aspect and Modality.

\footnotetext{
${ }^{9}$ The names of Bantu languages are given without their prefixes, in accordance with standard English usage.
} 


\begin{tabular}{|c|c|c|}
\hline & Zulu (Doke 1950: 99-110) & Tswana (Cole 1975: 138-40; 173-4) \\
\hline 'True' adjectives & 'c' = I; 'q' =! & \\
\hline \multicolumn{3}{|l|}{ Qualitative } \\
\hline 'short' & -fuphi & -khutšhwabe \\
\hline 'nice, good, beautiful' & -hle & $-n t l \hat{e}$ \\
\hline 'black' & & $-n t s ̌ h o$ \\
\hline 'new, young, fresh' & $-s h a$ & $-\check{s} a, f \check{s} a$ \\
\hline 'very small' & $-n c i$ & -nye, -ntfe \\
\hline \multicolumn{3}{|l|}{ Quantifying } \\
\hline 'much, many' & $-n i n g i$ & $-n t s i$ \\
\hline 'other, some' & $-n y e$ & -ngwe \\
\hline 'two' & $-6 i l i$ & -bêedi \\
\hline \multicolumn{3}{|l|}{ Interrogative } \\
\hline 'how many?' & -ngaki? & \\
\hline 'what colour?' & & -tsiang?, -tšang?, -tsabang? \\
\hline \multicolumn{3}{|l|}{ Relative stems } \\
\hline \multicolumn{3}{|l|}{ Qualitative } \\
\hline 'black' & -mnyama & \\
\hline 'strong, hard, difficult' & -qatha & -thata \\
\hline 'pleasant' & -mnandi & -monate [denom] \\
\hline 'wet, damp' & $-m a n z i[$ denom $]$ & -mêtse [denom] \\
\hline 'sharp' & -bukhali [denom] & -bogale [denom] \\
\hline 'acid, salty' & - -типуи [denom] & \\
\hline \multicolumn{3}{|l|}{ Interrogative } \\
\hline 'how much, many?' & -ngakanani? & \\
\hline 'of what kind?' & -njani? & \\
\hline 'how much, how big?' & & $-k a e ́ ?$ \\
\hline \multicolumn{3}{|l|}{ Deictic } \\
\hline 'like this' & $-n j e$ & \\
\hline 'like that' & -njalo & \\
\hline 'like yonder' & -nje:yá & \\
\hline 'so much/big as this' & -ngaka & $-k a n a$ \\
\hline 'big as that' & -ngako & $-k a l o$ \\
\hline 'big as yonder' & -ngakayá & \\
\hline
\end{tabular}

All things considered, there would seem to be no compelling evidence for the 'otherness' of the languages spoken by the imagined 'first layer' of people in southern Africa. Guidelines that seem to have been flouted in constructing such a layer include the principle that linguistic difference should not be pre-supposed on the basis of biological or anthropological considerations, and the principle that it is a good idea to know the linguistic neighbours of a language under study.

Construction of an intermediate layer, supposedly contributed by the arrival of Khoe (or 'KhoeKwadi') speakers.

The Khoe languages are distinguished from the Ju and !Ui-Taa groups by their preference for a basic verb-final pattern. These languages also feature serial verb (or possibly multi-verb) constructions, and may manifest lexicalised compounds (or 'double verbs') that probably arise from the former. Nouns are sub-categorised as 'masculine', 'feminine' or 'common', where assignment is epistemically based in cases where natural gender applies, but otherwise arbitrary, although the masculine gender may carry connotations of greater height or length. Nouns may be reassigned to one or other of these genders, in which case the resulting implicational overlay may be augmentative, and is usually 
pejorative. The gender systems of languages in the Khoekhoe branch of Khoe are of an overt type, in that the genders of the nouns are explicitly indexed by post-placed affix morphemes. ${ }^{10}$

As noted earlier, there is a long history to the theory that speakers of the Khoe languages were perhaps the earliest pastoralists to enter the region. In fact, two slightly different versions of the model have been put forward at various times. In the Hamitic scenario, the general connection proposed is between certain northern languages belonging to families that are today classified as Afroasiatic - and languages of the southern African Khoe family. The idea was first proposed by Bleek (1851), who suggested a connection between such languages as Coptic and Galla, and the Khoekhoe languages of South Africa, where the latter were at that time known to him only from some early fragments of $17^{\text {th }}$ century Cape Khoekhoe and a few missionary texts.

Bleek's hypothesis, based on resemblances involving aspects of nominal gender morphology, and a few other items such as a causative, must have seemed convincing at the time. After all, the likeness was somewhat intriguing, as the examples in Illustration 2 show.

\begin{tabular}{|c|c|c|c|}
\hline \multicolumn{4}{|c|}{$\begin{array}{l}\text { Illustration } 2 . \\
\text { i.Suffixes of the } 3^{\text {rd }} \text { person associated with the } \\
\text { gender system of Nama (after Rust 1965). }\end{array}$} \\
\hline & $\mathrm{Sg}$ & Dual & Plural \\
\hline Masculine & $-b$ & $-k h a$ & $-g u$ \\
\hline Feminine & $-S$ & $-r a$ & $-t i$ \\
\hline Common & $-i$ & $-r a$ & $-n$ \\
\hline \multicolumn{4}{|c|}{$\begin{array}{l}\text { ii.Suffixes of the } 3^{\text {rd }} \text { person associated with the } \\
\text { gender system of Ancient Egyptian and later Coptic } \\
\text { (after Loprieno 1995:67). }\end{array}$} \\
\hline & $\mathrm{Sg}$ & Dual & Plural \\
\hline Masculine & $-f$ & & $-w j$ [vb suffix] \\
\hline Feminine & $-s$ & & $-t j$ [vb suffix] \\
\hline Common & & $-s n j$ & $\begin{array}{l}-s n \text { (Early) } \\
-w \text { (Late) }\end{array}$ \\
\hline
\end{tabular}

A similar idea was put forward by Lepsius (1880), and was later expanded by Meinhof (1912), who developed it into the full-blown Hamitic hypothesis. In an extension of the Hamitic hypothesis, a link between Sandawe and Nama was proposed by Dempwolff (1916).

Cust, on the other hand, while convinced that a northern group of people must have found their way to the southern part of Africa, indicated some doubt (1883:435) that these incoming people were necessarily related to speakers of Nubian or other 'Hamitic' languages. His alternative theory might be described as an early statement of the 'macro-Khoisan' scenario, and much the same belief was later expressed by Johnston (1919: 23-24):

We may imagine $[\ldots]$ some two thousand years ago, a South Africa beyond the Zambezi and Kunene rivers given up for a time to the dwarfish, steatopygous, yellow-skinned, clickusing Bushman. The next disturbing element may have been the Hottentot; a hybrid between negro and negroid and some more northern Bushman race, which seems to have migrated from Equatorial East Africa south-westwards to the Central Zambezi and thence to the

\footnotetext{
${ }^{10}$ The genders of Khoekhoe nouns are expressed by the suffixes $-b(i)$ 'masculine' (plural $-k u$ or $-k u(a)$ ) and $-s$ 'feminine' (plural $-d i$ or $-t i$ ). A singular for the common (or neutral) gender is occasionally expressed by $-i$ (with plural $-n$ ). In the case of Kalahari varieties other than Naro, genders are often expressed through agreement morphology alone, while the morpheme associated with the masculine singular is typically $-m(i)$. Identical morphemes function as dependent pronouns that may attach to other parts of speech for purposes of both discourse deixis and derivation.
} 
Atlantic coast near Walfish Bay, and on again southwards till the Hottentots entered (what is now) Cape Colony and displaced the Bushman.

In a recent reformulation of these ideas (Güldemann 2008), a group of supposed 'Khoe-Kwadi' speakers, who 'involve genetic profiles of both the Khoisan and Other-African type', ${ }^{11}$ are proposed to have entered the region a few centuries ahead of any Bantu-speaking communities, bringing with them the earliest domesticated livestock. It is suggested that these 'Khoe-Kwadi speakers', who may have come from somewhere in eastern Africa (p.119), encountered on their arrival in the far south 'a different indigenous language group' (p.111). It is added in this argument (p.116) that these preexisting speakers of the 'Non-Khoe' languages (Ju and !Ui-Taa) have a 'homogenous non-linguistic profile in that all relevant groups are foragers and show a strong genetic Khoisan profile' (p.116). In short, the speakers of the Ju and !Ui-Taa languages are assumed to be the aboriginal or 'pristine' hunter-gatherer inhabitants of the region - where this belief is supported by an appeal to biology, insofar as these speakers are explicictly stated to be genetically (which is to say, racially) different from other African communities. Two of the main components of this argument are considered next.

\section{The Khoe-Kwadi hypothesis.}

The Kwadi language of southern Angola was briefly recorded by the anthropologist De Almeida in 1955, who reported (1994:240) that 'only four or five' senior men still spoke it, while 'their men, in particular, can speak Portuguese and also the language of the Kwanyoka.' Westphal (1963) reported that he went to Lisbon during December to January 1956/7, to work with Almeida on his recordings of the Kwadi material. The notion that Kwadi might be very distantly related to the Khoe family was tentatively explored by Westphal, although he was inclined in the end (1971) to leave it classified as an isolate click language.

The feature of Kwadi that seems to have persuaded Westphal most strongly that the language was not Bantu was a pattern involving the infinitive verb, which he took took to reflect an infixed particle -la. It appears, however, that what is essentially involved is a system of reduplication or partial reduplication (as noted by Güldemann 2013b:263), with the occasional incorporation of a verbal extension or some other morpheme. Some of these verbs are plainly Bantu, as shown in Illustration 3.

\begin{tabular}{|c|c|c|c|}
\hline \multicolumn{4}{|c|}{$\begin{array}{l}\text { Illustration 3. Examples of reduplicated or partially reduplicated verb stems in Kwadi. } \\
\text { Sources of data are listed at the end of the paper. The letters H or L indicate tones. }\end{array}$} \\
\hline English & Other & Proto-Bantu & Kwadi \\
\hline 'read' & -tjanga 'write' [Herero] & & tayga-tayga [HH-LL] \\
\hline 'drink’ & -kalametsa [Tswana] & & kala-ka [HH-L] \\
\hline 'cry' & -lela [Tswana]; -lila [Ndonga] & $*$-did-a & tyeta-tyee [HH-L] \\
\hline 'put' & -pela 'give' [Kwanyama] & *-pá 'give' & pela-pe \\
\hline 'touch, feel' & -papatela 'hold' [Kwanyama] & *-pát-a 'hold' & pata-papata [HH-HHL] \\
\hline
\end{tabular}

The other seemingly different and potentially Khoisan-like feature of Kwadi was a system of nominal suffixes. (It may be noted that some Bantu languages of the same neighbourhood, such as Herero, regularly feature enclitic postnominal particles arising from a series of demonstrative morphemes with weak deictic force.) In the end, while Westphal identified a system of nominal genders indexed by the suffixes and involving masculine and feminine sub-categorisations, and while he even believed he had found evidence of a dual, the suffixed morphology supposedly associated with the relevant agreement classes is not used with any great consistency, and bears only a slight resemblance to that of the Khoe languages. Examples of these suffixes, such as $-d i,-n d i$ and $-i$ in the case of various singulars, can be seen in Illustration 4 (overleaf).

\footnotetext{
${ }^{11}$ The term 'Other African' is a euphemistic substitution by Güldemann for the more frankly offensive term, 'Negroid'.
} 
It appears from the limited material available that there were only a few dozen click words in Kwadi. The click most commonly used was the dental click, although one or two of the words are indicated with alternative pronunciations involving either a lateral click or the palato-alveolar. In short, the presence and distribution of clicks in this language does not seem to have been much greater than that which we see in Bantu languages of the Kwangari group, namely Mbukushu, Manyo (or Gciriku) and Kwangari .There are certainly a few words in Kwadi - including some of the click words - that appear to be 'Khoe-like'. However, these few isolated words bear such a close resemblance to items of Khoe vocabulary, possibly from the Khwe language in particular, that the greatest likelihood is that they are direct loans, rather than evidence of any relationship.

In fact, by far the greatest part of the Kwadi vocabulary appears to be from a Bantu language - though not the Kwanyama-like language, Kwanyoka, that was predominantly used by the Kwadi and is occasionally reflected along with Portuguese in Westphal's transcriptions as one of the two languages used by Almeida for purposes of communication and elicitation. Whereas Kwanyoka features the preprefix $\mathbf{0}$ - that is characteristic of certain noun classes in the western Bantu languages of Guthrie Zone R, such as Herero (R31) or Kwanyama (R21), the Bantu words in Kwadi are lacking in this element, so that they more closely resemble languages from groups of Zone $\mathrm{K}$, such as the Lwena-Luvale group (K14) or the Kwangari group (K33). Examples are given in Illustration 4.

\begin{tabular}{|c|c|c|c|c|}
\hline English & Other & Proto-Bantu & Kwanyoka & Kwadi \\
\hline 'hunter' & oти-kongo [Kwanyama] & *-kong- 'hunt' & & $m u$-kongo-di [H-HL-L] \\
\hline 'widower' & оти-hери-ndu [Herero] & - & & mu-hepe-e [H-LLL] \\
\hline 'hide, skin' & oти-kova $[$ Herero] & *-kóbá & & mu-kotya \\
\hline 'White man' & osi-ndele [Kwanyama] & & & tçi-dele \\
\hline 'day’ & - & *-kùmbì 'sun' & & tçi-kume \\
\hline 'root' & omu-di [Kwanyama] & *(3)-dì & omwi-ji & $t / i-m u-\theta i-i$ \\
\hline 'pig' & ofi-ngulu [Kwanyama] & *(9)-gùdú & & tfungutu-i [LLL-L] \\
\hline 'tree' & omu-ti [Kwanyama] & $*(3)-\mathrm{tí}^{2}$ & $o m u-t i$ & $t / i-d i$ \\
\hline 'ashes' & - & *(3)-tó & $e$-to & tsu-ndi \\
\hline 'egg' & $e-i[$ Kwanyama] & $*(5)$-gí & & $i-d i$ \\
\hline 'axe' & - & $*(5)$-gèmbè & & $k x^{\prime} e \beta e$ \\
\hline 'pool, lake' & - & *(9)-jádé 'river' & & fade \\
\hline 'rhino' & omanda [Kwanyama] & $*(9)$-panda & & phala-de [HH-L] \\
\hline 'scorpion' & on-dje [Kwanyama] & $*(9)$-ge & & $g e$ \\
\hline 'bull' & oniuedi 'bull' [Kwanyama] & $*(9)$-kuidi 'bull' & & gwedi \\
\hline 'goat' & $o s i-k^{h}$ ombo [Kwanyama] & *(9)-kómbò & & $\left.k x^{\prime} \supset-(k) x^{\prime}\right\lrcorner b o-d i[\mathrm{H}-\mathrm{HL}-\mathrm{L}]$ (male) \\
\hline 'snake' & onyoha [Umbundu] & *(9)-jókà & & kx's-nuwз-di [H-HL-L] (male) \\
\hline 'chicken' & sanji [Kimbundu] & $*_{\text {-cangi }}$ & & k'ie-saygyi [HL-LL] (female) \\
\hline
\end{tabular}

To sum up: the evidence for a familial connection between the Khoe languages and Kwadi is slight; on the other hand, there is reasonable evidence that Kwadi was most probably a Bantu language at heart, with a few unusual features, and a small complement of words borrowed from a range of sources.

It is worth adding, nevertheless, that the set of number names is particularly eclectic, and includes two terms borrowed from a Khoe source (for 'one' and 'two'), plus a pair for 'six' and 'seven' where the terms are reversed forms of typical Kwanyama number names, with Kwadi $\mid i^{t}$ nau, for example, substituting for Kwanyama ñano na imue 'six'. These inversions are so strongly suggestive of deliberate manipulation that it begins to seem a possibility that 'Kwadi' may have been some kind of 'inner language'. This likelihood is strengthened by De Almeida's (1994:240) curious comment that: 
The younger generation do not know it [Kwadi], either because they did not learn it, as it was a difficult language (a "heavy one") or "because they had grown up among the Whites", these being the words I have often heard from them.

A natural language is, of course, not normally learned in any formal sense, nor does it seem 'heavy' to its speakers. The fact that at the time of its documentation Kwadi was still used only by the men of a particular age grade suggests that it may have been an old initiation language, of the kind that would have had to be specially learned and might well have seemed 'heavy' to young inititiates.

The use of such auxiliary codes, at least in earlier times, has been documented throughout Africa. Their use sometimes reflects respect shown by one sub-group to another, for example by women towards men, initiates towards their mentors, or commoners towards royalty; but in other cases it seems to have been favoured as a kind of powerful 'inner language' used by the members of elite groups or 'guilds', such as rainmakers, healers, musicians, metal-workers, or soldiers belonging to a royal garrison. Storch (2011:31) refers to various other 'craft registers', and quotes the example of the 'secret language of sculptors' set out in an Ancient Egyptian inscription dating from c.2066-2040 BCE. The special lexis used by members of various professional groups in traditionalVenda society is documented by Van Warmelo (1989), while the auxiliary codes used, sometimes for years on end, by initiates into the To and Labi secret societies of the Gbaya were described by Tessmann (1931). The use of 'special languages' was also sometimes associated with worship and spiritual intermediation.

The argument for a link between Khoe languages and the east African click language, Sandawe.

Even if there is no ancestral 'Khoe-Kwadi', it remains open that speakers of the Khoe languages might have trekked down the continent perhaps two or three thousand years ago, bringing sheep or goats with them from somewhere in eastern Africa. After all, as noted above, the gender-associated morphology of the Khoe pronominal system certainly bears an uncanny resemblance to equivalent systems in Afroasiatic languages. Indeed, the affinities that Elderkin (1986) proposes as evidence for a Sandawe-Khoe connection could just as well be interpreted as evidence for a Sandawe-Afroasiatic connection.Yet, if it is a north-eastern connection involving some Afroasiatic affinity that is proposed for Khoe, on structural grounds, then it is puzzling that nothing of this kind is reflected in the Khoe vocabulary.

Alternatively, if we wish to discard the 'Hamitic' version of the theory and argue instead with Cust (1883) and Johnston (1919) that the north-east African link involves some purely Khoisan ancestor, then we should probably try, as a precautionary measure, to eliminate from our supporting evidence any aspects of Sandawe that appear to be either Bantu or Cushitic. (Dempwolff (1916) identified a substantial proportion of words in the Sandawe lexicon that were Bantu, as well as a group of words that he clearly interpreted as borrowings from a Cushitic source.)

The difficulty here is to find words that truly reflect a unique 'Khoesan-ness', since, in reality, part of the vocabulary reconstructed for Proto-Khoe (Vossen 1997) appears to be Bantu. Firstly, there are a number of 'non-click' words that fall into this category, as shown in Illustration 5 (overleaf). (There are several more examples not included here because they are less clearcut, while in addition, the Khoe languages contain numerous words of Bantu origin not reconstructed for the ancestral language.) It is nevertheless intriguing that one or two of the Bantu words in Illustration 5 seem to be characteristic of central Africa. For example, the Proto-Bantu reconstruction *-dámì for 'tongue' has known reflexes only in Guthrie Zones C and D, which is to say in the central or interlacustrine regions of Africa. 


\begin{tabular}{|c|c|c|c|c|c|c|}
\hline gloss & Proto-Khoe & & & Proto-Bantu & & \\
\hline 'see' & $\begin{array}{l}\text { *mũ } \\
{[\mathrm{PKalK}]}\end{array}$ & Nama: & $\begin{array}{l}m \hat{u} \\
\text { [muu }]\end{array}$ & *-bón-a [wide] & $\begin{array}{l}\text { Herero: } \\
\text { Kwany: }\end{array}$ & $\begin{array}{l}\text {-muna }(u) \\
\text {-mona }\end{array}$ \\
\hline 'tongue' & *dam [PKalK] & Khwe: & dàḿ & *-dámì [CD] & & \\
\hline $\begin{array}{l}\text { 'swallow' } \\
{[\mathrm{vb}]}\end{array}$ & $\begin{array}{l}\text { *tom [PK:PKK]; } \\
\text { *tóm [PKalK] }\end{array}$ & Nama: & tom & $\begin{array}{l}\text { *-tóm-a } \\
\text { [CDELM] 'chew, } \\
\text { drink' }\end{array}$ & & \\
\hline 'night' & *thŭ [PKalK] & Khwe: & thùú & *-túkù [wide] & Xhosa: & ubu-suku \\
\hline $\begin{array}{l}\text { 'medicine, } \\
\text { magic' }\end{array}$ & $\begin{array}{l}\text { *tso [PK:PKalK]; } \\
\text { *so [PKK] }\end{array}$ & Khwe: & tcóò & $\begin{array}{l}\text { *-dòg- 'bewitch, } \\
\text { curse' [wide] }\end{array}$ & Tswana: & $\begin{array}{l}\text { toô 'witchcraft' } \\
<- \text { loa 'cast spell' }\end{array}$ \\
\hline sprout & $\begin{array}{l}\text { *tsom [PKalK; } \\
\text { PWK], } \\
\text { *tsòm [PEK] }\end{array}$ & Khwe: & tcòm & $\begin{array}{l}* \text {-com- }[\mathrm{AS}] \\
\text { 'sprout' }\end{array}$ & $\begin{array}{l}\text { Xhosa: } \\
\text { Sotho: } \\
\text { Venda: }\end{array}$ & $\begin{array}{l}\text {-hluma } \\
\text {-hloma } \\
\text {-tuma }\end{array}$ \\
\hline ‘lip’ & $* \mathrm{ts}^{3}$ om $[\mathrm{PKalK}]$ & Khwe: & tc'óm & $\begin{array}{l}\text { *-dòmò [wide] } \\
\text { 'lip, mouth,beak' }\end{array}$ & Venda: & $\begin{array}{l}\text { domo (5) 'big } \\
\text { mouth', } \\
\text { [aug of mu-lomo ] }\end{array}$ \\
\hline 'breast' & $\begin{array}{l}\text { *sam [PK]; } \\
\text { *sam [PKalK, } \\
\text { PEK] }\end{array}$ & Nama: & sam-s & $\begin{array}{l}\text { *-jámu- 'suck' } \\
\text { [EGKLMRS] }\end{array}$ & $\begin{array}{l}\text { Karanga: } \\
\text { Venda: }\end{array}$ & $\begin{array}{l}\text { zamu } \\
\text { damu }\end{array}$ \\
\hline 'charcoal' & $\begin{array}{l}\text { *gada [PKalK; } \\
\text { PEK] }\end{array}$ & Shua: & gada & *-kádà [wide] & Tswana: & ma-gala \\
\hline 'navel' & $\begin{array}{l}\text { *gobo [PKalK, } \\
\text { PEK] }\end{array}$ & Khwe: & gòvó & $\begin{array}{l}\text { *-kóbú [AGJKS] } \\
\text { 'navel' }\end{array}$ & Tswana: & khubu \\
\hline 'year' & *kudi [PK] & $\begin{array}{l}\text { Nama: } \\
\text { Khwe: }\end{array}$ & $\begin{array}{l}\text { kuri-b } \\
\text { kúrí }\end{array}$ & $\begin{array}{l}\text { *-kútì [ADJ] } \\
\text { 'cloud' }\end{array}$ & Karanga: & gole 'cloud, year' \\
\hline
\end{tabular}

Secondly, there are two classes of cross-Khoe comparative series where some of the cognates are words with clicks as initial segments, but others (typically from varieties of Eastern Kalahari Khoe) are not - and where the latter 'non-click' words are recognisably Bantu. Illustration 6 shows a few examples of these mixed series, from the class involving the palato-alveolar click [ $\ddagger]$.

\begin{tabular}{|c|c|c|c|c|c|c|}
\hline \multicolumn{7}{|c|}{$\begin{array}{l}\text { Illustration 6. Examples of cross-Khoe comparative series where the palato-alveolar click alternates with a } \\
\text { conventional segment - and where the 'clickless'form (bolded) is recognisably Bantu. }\end{array}$} \\
\hline gloss & Proto-Khoe & language & & Proto-Bantu & language & \\
\hline 'black' & 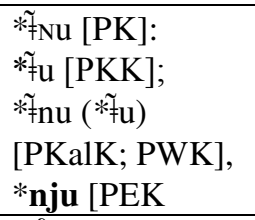 & $\begin{array}{l}\text { Nama: } \\
\text { Naro: } \\
\text { Shua: } \\
\text { Tshua: }\end{array}$ & $\begin{array}{l}\neq n u u ̀ ~ \\
n \neq u ̀ u ́ \\
n j u ́, y u ́ \\
n d u ́\end{array}$ & $\begin{array}{l}\text { *-jídì [wide] } \\
<* \text {-jìd-a [FH] } \\
\text { 'bec. dark' }\end{array}$ & $\begin{array}{l}\text { Kgala: } \\
\text { Tswana: } \\
\text { Sotho: } \\
\text { Venda: }\end{array}$ & $\begin{array}{l}-n t s^{h} o \\
-t \int o \\
-t s^{h} o \\
-t s^{w} u\end{array}$ \\
\hline $\begin{array}{l}\text { 'food, } \\
\text { foodstuffs' }\end{array}$ & $\begin{array}{l}*_{\ddagger}^{?} \tilde{u} \text { 'food' }[\mathrm{PK}] \\
*^{2} \mathbf{y} \tilde{\mathbf{u}}[\mathrm{PEK}]\end{array}$ & $\begin{array}{l}\text { Nama: } \\
\text { Naro: } \\
\text { Shua: }\end{array}$ & $\begin{array}{l}\ddagger^{\prime} u \tilde{u b}\left[\mathrm{LH}^{\prime}\right] \\
\ddagger^{\prime} \tilde{o} o \\
{ }^{2} y \tilde{u}\end{array}$ & $\begin{array}{l}*(7) \text {-díò } \\
{[\text { EGJLMNPS] }}\end{array}$ & $\begin{array}{l}\text { Tswana: } \\
\text { Venda: } \\
\text { Kwany: }\end{array}$ & $\begin{array}{l}\text { di-yò } \\
\text { nndyo } \\
e \text {-lyo 'eating' }\end{array}$ \\
\hline 'egg' & 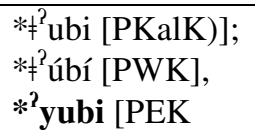 & $\begin{array}{l}\text { Naro: } \\
\text { Shua: }\end{array}$ & 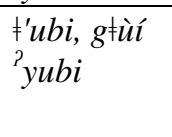 & $\begin{array}{l}\text { *(5)-túmbí } \\
\text { [EMNP] } \\
\text { 'egg' }\end{array}$ & Xhosa & $\begin{array}{l}u m-t^{h} u b i \\
\text { 'yolk, colostrum' }\end{array}$ \\
\hline
\end{tabular}


Despite such evidence for the great likelihood of click emergence, ${ }^{12}$ the assumption has been made in formulating the reconstructions for Proto-Khoe that processes of click loss must have operated, and the relevant segments are accordingly projected as clicks. On one hand, it can be argued that this decision is in accordance with the historical linguist's rule of thumb known as 'Majority Rules'. However, the decision violates the rule of thumb known as Lass's 'Oddity Constraint' - which is itself a version of Occam's Razor.

Overall, the picture remains somewhat complex, and while the possibility of some north-eastern or central African connection cannot be completely discounted, it is unclear what the nature of that regional affinity might have been, and what source languages are ultimately involved. At very least, though, it seems questionable that there is any intermediate linguistic stratum with a specifically 'Khoe-like' character. Rather, it begins to look as though we ought to be considering the possibility of a Bantu-like stratum.

The guidelines that have been ignored in formulating the notion of an intermediate layer include the principle that resemblances of a physiological or cultural nature do not constitute evidence that the languages of the communities concerned are related - in as far as it has evidently been assumed on the basis of physical appearance that some northern population group might be involved, and in as far as it has even been proposed to seek genetic corroboration for the theory. The decision to reconstruct words with clicks - when they appear to have unmistakeable Bantu antecedents - seems to have involved a flouting not only of the Principle of Parsimony, but also of the principle that it is generally wise to be mindful of neighbouring languages when working on a particular language group.

\section{Conclusion.}

It has been attempted in the brief studies above to show how often and how far we have wandered astray in contemporary Khoesan Linguistics, and it has been suggested that we have made these errors through failure to pay attention to the steady stars that should be our compass. This failure would seem to have come about because of our inability to shake off an overwhelming belief that perceptions of otherness have some absolute and meaningful value, and that they take precedence over fundamental principles.

\section{Acknowledgements.}

A much earlier version of this paper was originally intended as a contribution towards a book that was being edited by the historian Mike Besten at the time of his premature death. I am most grateful for the opportunity I was given to present the chapter as a work in progress at a one-day symposium in the Department of Anthropology at the University of the Free State, in July 2010; and I am indebted to Chris Rapold for useful comments contributed by him on that occasion. This was while I was a postdoctoral research fellow at the University of Cape Town in 2010, and I am thankful for support received at that time in the form of funding from the NRF and a departmental scholarship from the Linguistics Section at UCT.

The current form of the paper reflects extensive revision and is effectively new work. This version has benefited from informal feedback received from various colleagues who participated in the Research Seminar on Khoi and San Representation convened by Michael Wessels and held at the University of Kwazulu-Natal (Pietermaritzburg) April 2013. In particular I am deeply grateful for ongoing correspondence with Anne Solomon, John Wright and Jill Weintroub. I am also most grateful to two anonymous reviewers for their careful reading of this paper and constructive comments: I have tried to implement every one of their suggestions.

Lastly, I am most thankful to the Department of Linguistics at Stellenbosch University for providing me with a supportive collegial environment and an academic home.

\footnotetext{
${ }^{12}$ At a subsequent conference held at the University of the Witwatersrand (August 7-10, 2013), the suggestion was made in a keynote address by Maddieson (2013) that clicks could, in principle, emerge from certain phonetic environments, such as those that occur naturally in languages of the Shona group (Guthrie Zone $\mathrm{S}$ ) and Rundi-Rwanda (Guthrie Zone DJ60). At the same conference, Demolin and Chabiron (2013) independently demonstrated the actual emergence of clicks in just such environments in Rwanda.
} 
Abbreviations.

$\begin{array}{ll}\text { aug } & \text { Augmentative } \\ \text { denom } & \text { Denominative } \\ \text { Kgala } & \text { Kgalagadi } \\ \text { Kwany } & \text { Kwanyama } \\ \text { PB } & \text { Proto-Bantu } \\ \text { PEK } & \text { Proto-Eastern Kalahari Khoe } \\ \text { PK } & \text { Proto-Khoe } \\ \text { PKalK } & \text { Proto-Kalahari Khoe } \\ \text { PKK } & \text { Proto-Khoekhoe Khoe } \\ \text { PWK } & \text { Proto-Western Kalahari Khoe } \\ \text { sg } & \text { Singular } \\ \text { vb } & \text { Verb }\end{array}$

Sources of data used in the tables.

Note: The Bantu languages are grouped according to their Guthrie numbers, as updated by Jouni Maho (2009). These divisions are primarily geographic, although genealogical groupings may sometimes coincide with them.

\section{Khoesan languages.}

Khoe.

Proto-Khoe: Vossen (1997)

Khoe: Khoekhoe branch

Nambian Khoekhoe (Nama, Dama, HaillOm): Haacke and Eiseb (2002)

Khoe: Kalahari branch

Khwe: Kilian-Hatz (2003)

Naro: Visser (2001)

Eastern varieties (Shua, Tshua): Vossen (1997)

Kwadi.

Westphal (1956/7)

Bantu languages.

Proto-Bantu: Bastin and Schadeberg (eds) (2005)

S40: Nguni Group

S41: Xhosa: McLaren (1963); Fischer, Weiss, Mdala, \& Tshabe ( 2006)

S30: Sotho-Tswana Group

S31: Tswana: Brown (1982)

S33: S. Sotho: Mabille and Dieterlin, rev. Paroz (1988)

S311: Kgalagadi: Dickens (1986)

\section{S20: Venda Group}

S21: Venda: Van Warmelo (1989)

S10: Shona Group

S14: Karanga: Louw (1915)

H20: Kimbundu Group

H21a: Kimbundu, Ngola: Pereira do Nascimento (1903)

R10: Umbundu Group.

R11: Umbundu: Schadeberg (1990) 
R20: Wambo Group

R21: Kwanyama: Tobias and Turvey (1954)

R22: Ndonga: Viljoen, Amakali and Namuandi (2004)

\section{R30: Herero Group}

R30: Herero: Viljoen and Kamupingene (1983)

References.

Ashton, E. O. 1947. Swahili Grammar (Including Intonation). Harlow, Essex: Longman.

Bastin, Y. and T. C. Schadeberg (eds). 2005. $3^{\text {rd }}$ Tervuren series of Bantu lexical reconstructions (BLR3). Consulted online throughout 2012, at http://www.metafro.be/blr

Baucom, K. L. 1974. 'Proto-Central Khoisan.' In E. Voeltz (ed.): $3^{\text {rd }}$ Annual Conference on African Linguistics. Bloomington: Indiana University Publications.

Beach, D. M. 1938. The Phonetics of the Hottentot Language. Cambridge: Heffer.

Bleek, Dorothea. 1927. 'The distribution of Bushman languages in South Africa.' In Festschrift Meinhof, 55-64 Hamburg: Augustin.

1929. Comparative Vocabularies of Bushman Languages. Cambridge: Cambridge University Press.

2000. 'The ॥ $\mathrm{D}$ !ke or Bushmen of Griqualand West.' (Ed. Tom Güldemann. ) Cologne: Khoisan Forum Working Paper 15.

Bleek, W. H. I. 1851. De nominum generibus linguarum Africa australis, Copticae, Semiticarum aliarumque Sexualium. Bonn: Adolph Marx.

1862. A Comparative Grammar of South African Languages. Part I. London: Trübner \&Co.

1911. '"The Resurrection of the Ostrich": part of the preceding tale parsed by Dr Bleek.' In W.H.I. Bleek and Lucy Lloyd (eds): Specimens of Bushman Folklore, 144-154. London: George Allen \& Co., Ltd.

Brown, J. Tom, 1982. Setswana Dictionary: Setswana-English and English-Setswana. Johannesburg: Pula Press.

Cole, D. T. 1975. An Introduction to Tswana Grammar. Cape Town: Longman.

Cust, Robert Needham. 1883. A Sketch of the Modern Languages of Africa. London: Trübner and Co.

De Almeida, A. 1994. Os Bosquimanos de Angola. Lisbon: Instituto de investigação cientifica tropica.

De Maret, P. and F.N. Nsuka 1977. 'History of Bantu metallurgy: some linguistic aspects.' History in Africa 4:43-65.

Demolin, Didier and Clothilde Chabiron. 2013. 'Clicks, stop bursts, vocoids and the timing of articulatory gestures in Rwanda.' Paper presented at the conference on Phonetics and Phonology of Sub-Saharan Languages, July7-10, 2013, University of the Witwatersrand, Johannesburg.

Dempwolff, O. 1916. Die Sandawe. Linguistiches und ethnographisches Material aus Deutsch-Ostafrika. (Abhandlungen des Hamburgischen Kolonialinstituts: 34.B. Völkerkunde, Kulturgeschichte und Sprachen: 19.) Hamburg: L.Friederichsen.

Dickens, Patrick.1986. Qhalaxarzi Phonology. Masters Dissertation. Johannesburg: University of the Witwatersrand.

Doke, C. M. 1937. 'An outline of łKhomani Bushman phonetics.' In J.D. Rheinallt Jones and C. M. Doke (eds): Bushmen of the Southern Kalahari. Johannesburg: Witwatersrand University Press.

1950. Textbook of Zulu Grammar. London: Longmans, Green and Co. Ltd.

Doke, C. M. and S. M. Mofokeng. 1985. Textbook of Southern Sotho Grammar. Cape Town: Maskew Miller Longman.

Dornan, S.S. 1917. 'The Tati Bushmen (Masarwas) and their language.' Journal of the Royal Anthropological Institute, 47 (Jan-June): 37-112.

Du Plessis, Menán. 2013. 'New data on click genesis: further evidence that click-initial words shared by Khoesan and Bantu languages of southern Africa can be mapped as historically emergent from nonclick forms reconstructed for Proto-Bantu.' Paper presented at a conference on the Phonetics and Phonology of Sub-Saharan Africa, held in honour of the late Tony Traill at the University of the Witwatersrand, July 7-10, 2013.

Forthcoming. 'One hundred years of the Specimens - a hundred years of linguistic neglect.' Paper delivered at a conference to mark the publication centenary of Specimens of Bushman Folklore, UCT, 17-20 August 2011. [To appear in J. Deacon and P. Skotnes (eds): The Courage of $\|$ Kabbo.]

In Preparation. 'The systematic occurrence of Bantu-intrinsic click words in Khoesan languages, discovered by reference to reconstructions for Proto-Bantu.'

Elderkin, E.D. 1986 'Diachronic influences from basic sentence and noun structure in Central Khoisan and Sandawe.' Sprache und Geschichte in Afrika 7(2): 131-156. 
Engelbrecht, Jan. 1936. The Korana. Cape Town: Maskew Miller. (Previously published 1928, as 'Studies oor Korannataal'. Annale van die Universiteit van Stellenbosch. VI (2).)

Fisch, Maria (transl. S. Fitchat). 1998 [1977]. Thimbukushu Grammar. Windhoek: Out of Africa Publishers.

Fischer, A., E. Weiss, E. Mdala, S. Tshabe. 2006. English-Xhosa Dictionary. Cape Town: Oxford University Press, Southern Africa.

Greenberg, J.H. 1963. The Languages of Africa. Bloomington: Indiana University

Güldemann, Tom. 2004a. 'TUU - a new name for the Southern Khoisan family.' In T. Güldemann: Studies in Tuu (Southern Khoisan), 11-30. (University of Leipzig Papers on Africa, Languages and Literatures 23). Leipzig: Institut für Afrikanistik, Universität Leipzig.

2004b. 'Reconstruction through 'deconstruction': the marking of person, gender, and number in the Khoe family and Kwadi.' Diachronica 21(2):251-306.

2008. 'A linguist's view: Khoe-Kwadi speakers as the earliest food-producers of southern Africa.' Southern African Humanities 20:93-132.

2013a. 'Southern Khoesan (Tuu): Morphology; Syntax'. In Rainer Vossen (ed.): The Khoesan Languages, 234-248; 408-430. London and New York: Routledge.

2013b. 'Kwadi: Morphology.' In Rainer Vossen (ed.): The Khoesan Languages, 261-264. London and New York: Routledge.

Güldemann, T. and E. D. Elderkin. 2010. 'On external genealogical relationships of the Khoe family.' In M. Brenzinger and C. König (eds), Khoisan Languages and Linguistics: the $1^{\text {st }}$ Riezlern symposium 2003. (Research in Khoisan Studies 24). Cologne: Rüdiger Köppe.

Güldemann, T. and R. Vossen. 2000. 'Khoisan.' In B. Heine and D. Nurse (eds): African Languages: An Introduction, 99-122. Cambridge: Cambridge University Press.

Haacke, W. H. G. and Eliphas Eiseb. 2002. A Khoekhoegowab Dictionary. Windhoek: Gamsberg Macmillan.

Harries, Lyndon. 1950. A Grammar of Mwera. Johannesburg: Witwatersrand University Press.

Heine, Bernd and Henry Honken. 2010. 'The Kx'a Family: a new Khoisan genealogy.' Journal of Asian and African Studies 79:5-36.

Heine, Bernd. and Christa König. 2008. 'What can linguistics tell us about early Khoekhoe history?'Southern African Humanities 20:235-248.

Herbert, Robert K. and Richard Bailey. 2002. 'The Bantu languages: sociohistorical perspectives.' In R. Mesthrie (ed.): Language in South Africa:50-78. Cambridge: Cambridge University Press.

Honken, Henry. 2013. 'Genetic relationships: an overview of the evidence.' In Rainer Vossen (ed.): The Khoesan Languages, 13-24. London and New York: Routledge.

Johnston, H. 1919. A Comparative Study of the Bantu and Semi-Bantu Languages. Oxford: Clarendon Press.

Kilian-Hatz, C. 2003. Khwe Dictionary. Cologne: Rüdiger Köppe.

Köhler, O. 1971. 'Die Khoe-sprachigen Buschmänner der Kalahari: Ihre Verbreitung und Gliederung'. Furschungen zur allgemeinen und regionalen Geographie (Festschrift für Kurt Kayser):373-411. Wiesbaden: Franz Steiner. [Not seen.]

Lanham, L. W. and D. P. Hallowes 1956. 'Linguistic relationships and contacts expressed in the vocabulary of Eastern Bushman.' African Studies 15(1):45-48. Repr. in R. K. Herbert (ed.), Foundations in Southern African Linguistics, 253-256. Johannesburg: Witwatersrand University Press.

Lass, R. 1993. 'How real(ist) are reconstructions?' In C. Jones (ed.): Historical linguistics: Problems and perspectives, 156-189. London: Longman.

1997. Historical linguistics and language change. (Cambridge Studies in Linguistics 81) Cambridge: Cambridge University Press.

Lepsius, R. 1880. Nubische Grammatik, mit einer Einleitung über die Völker und Sprachen Afrika's. Berlin: Wilhelm Hertz.

Lichtenstein, Henry. 1815. Travels in Southern Africa in the Years 1803, 1804, 1805, and 1806. Vol. II. (Transl. Anne Plumptre). London: Henry Colburn.

Loprieno, Antonio.1995. Ancient Egyptian: A Linguistic Introduction. Cambridge: Cambridge University Press.

Louw, C. S. 1915. A Manual of the Chikaranga Language. Bulawayo: Philpott and Collins.

Mabille, A. and H. Dieterlen, reclassified, revised and enlarged R. A. Paroz. 1988. Southern-Sotho-English Dictionary (South African orthography). Morija: Morija Sesuto Book Depot.

McLaren, J. (revised W. G. Bennie and J .J. R. Jolobe). 1963. A New Concise Xhosa-English Dictionary. Cape Town: Longmans.

Maddieson, Ian. 2013. 'Clicks: Primordial or Derived?' Keynote address, given at the conference on Phonetics and Phonology of Sub-Saharan Languages, July7-10, 2013, University of the Witwatersrand, Johannesburg. 
Maho, Jouni. 2009. New Updated Guthrie List. Consulted online during September 2012 at http://goto.glocalnet.net/mahopapers/nuglonline.pdf

Maingard, L. F. 1937. ‘The łKhomani dialect of Bushman: its morphology and other characteristics.' In J. D. Rheinallt Jones and C. M. Doke (eds.): Bushmen of the Southern Kalahari. Johannesburg: Witwatersrand University Press.

Maingard, L.F. 1963. 'A comparative study of Naron, Hietshware and Korana.' African Studies 22(3):97-108.

Meinhof, C. 1912. Die Sprachen der Hamiten. Hamburg: L. Friederichsen and Co.

1928-1929. 'Versuch einer grammatischen Skizze einer Buschmannsprache.' Zeitschrift für Eingeborenen-Sprachen 19:161-88.

Moodie, D.1838. The Record; or, A Series of Official Papers Relative to the Condition and Treatment of the Native Tribes of South Africa. Cape Town: A.S. Robertson.

Nurse, Derek and Gérard Philippson. 2003. 'Introduction'. In Derek Nurse and Gérard Philippson (eds): The Bantu Languages:1-12. London: Routledge.

Pereira do Nascimento, J. 1903. Diccionario Portuguez-Kimbundu. Huilla: Typographia da Missão.

Sands, B. 2001. 'Borrowing and diffusion as a source of lexical similarities in Khoesan.' In A. Bell and P. Washburn (eds), Khoisan: syntax, phonetics, phonology, and contact, 200-224. (Cornell Working Papers in Linguistics 18). Ithaca, N.Y.: Cornell University.

Schadeberg, Thilo. 1990. A Sketch of Umbundu. Cologne: Rüdiger Köppe.

2003. 'Historical Linguistics'. In Derek Nurse and Gérard Philippson (eds): The Bantu Languages:143-163. London: Routledge.

Scott, D. C. and A. Hetherwick. 1957 [1929]. Dictionary of the Nyanja Language (being the Encyclopaedic Dictionary of the Mang'anja Language, edited and enlarged). London: Lutterworth Press.

Storch, Anne. 2011. Secret Manipulations: Language and Context in Africa. Oxford: Oxford University Press.

Tessmann, G. 1931. 'Die drei Sprachen des Bajastammes: To, Labi, Baja (Kamerun).' Mitteilungen des Seminars für Orientalische Sprachen 34 (3):70-115. Berlin.

Tobias, G. W. R. and B. H. C. Turvey. 1954. English-Kwanyama Dictionary. Johannesburg:Witwatersrand University Press.

Van Warmelo, N. J. 1989. Venda Dictionary: Tshivenda-English. Pretoria: J.L. van Schaik.

Viljoen, J .J., P. Amakali and N. Namuandi. 2004. Oshindonga/English; English/Oshindonga Dictionary. Windhoek: Gamsberg Macmillan.

Viljoen, J. J. and T.K. Kamupingene. 1983. Otjiherero Woordeboek/Dictionary/Embo Romambo. Windhoek: Gamsberg.

Visser, H. 2001. Naro Dictionary: Naro-English; English-Naro. Gantsi: Naro Language Project.

Vossen, Rainer. 1997. Die Khoe-Sprachen: Ein Beitrag zur Erforschung der Sprachgeschichte Afrikas. (Research in Khoisan Studies 12.) Cologne: Rüdiger Köppe.

Vossen, Rainer (ed.) 2013. The Khoesan Languages. (Routledge Language Family Series.) London and New York: Routledge.

Westphal, E. O. J. 1956/57. Manuscript Kwadi papers, amongst the Westphal Papers in the Unversity of Cape Town Libraries Digital Online Collections.

1963. 'The linguistic prehistory of southern Africa: Bush, Kwadi, Hottentot and Bantu linguistic relationships.' Africa 33: 237-65.

1971. 'The click languages of southern and eastern Africa.' In T. A. Sebeok (ed.), Linguistics in Sub-Saharan Africa. (Current Trends in Linguistics 7). The Hague and Paris: Mouton.

Wuras, C.F. 1919-1920 [c.1850] (Ed. W. Bourquin.) 'An outline of the Bushman language.' Zeitschrift für Eingeborenen-Sprachen X: 81-87.

Ziervogel, D. 1955. 'Notes on the language of the Eastern Transvaal Bushmen.' In E.F. Potgieter: The Disappearing Bushmen of Lake Chrissie: Pretoria: Van Schaik Ltd. 